\title{
MODERNISASI PENDIDIKAN ISLAM ABAD KE 20 DI SULAWESI SELATAN
}

\author{
Suyuti Gaffar* \\ Muhammad Takbir $\mathbf{M}^{* *}$
}

\begin{abstract}
Abstrak: Penelitian ini berusaha untuk menguak moderanisasi pendidikan Islam abad ke-20 di Sulawesi Selatan. Tujuannya, untuk memberikan gambaran atas pengalaman masa lalu pendidikan Islam di tempat ini, sehingga menjadi refleksi atas kenyataan hari ini. Metode penelitian yang digunakan ialah kualitatif yang mengacu pada studi kepustakan (research library). Sebagai hasilnya, diperoleh bahwa titik pijak modernisasi pendidikan Islam di tempat pada abad ke-20. Ini dapat dilihat melalui berdirinya Madrasah Arabiyah Islamiyah (MAI) Sengkang pada tahun 1930 - selanjutnya berubah nama menjadi As'adiyah Sengkang pada tahun 1953. MAI adalah lembaga pendidikan pertama di tempat ini yang menggunakan sistem formal dan kelas berjenjang, serta masukkan pelajaran umum dalam kurikulumnya sejak berdirinya.
\end{abstract}

Kata Kunci: Modernisasi, Pendidikan Islam, As’adiyah, Sulawesi Selatan

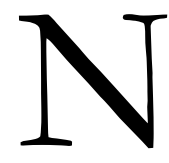

arasi tentang sejarah perkembangan pendidikan Islam di Indonesia, khususnya pesantren, setidaknya baru mendapat perhatian pada sekitar tahun 1970-an. Terlebih lagi, narasi tersebut cenderung memuat sejarah pesantren di sekitar wilayah Jawa dan Sumatera. Sementara, lembaga ini pun ada tersebar di dua pulai ini tapi seantero nusantara, dan tidak terkecuali di Sulawesi Selatan. Nurchoulis Madjid, dalam sebuah tulisannya

* Dosen Institut Agama Islam As'adiyah Sengkang Sulawesi Selatan. Email: suyutigafar@gmail.com

Alumni Magister Pendidikan Islam UIN Sunan Kalijaga Yogyakarta 
bahkan pernah mengatakan bahwa pesantren sebagai lembaga pendidikan Islam awal adalah indigenous Indonesia. Lebih jauh menurutnya, sekiranya negeri ini tidak pernah mengalami penjajahan mungkin perguruan tinggi seperti: Institut Teknologi Bandung (ITB), Institut Pertanian Bogor (IPB), Universitas Indonesia (UI), dan lain-lain, tidak dikenal, justru yang ada adalah Universitas Tambak Beras, Universitas Krapyak, dan lain-lain.

Perkembang pesantren mencapai puncaknya pada sekitar abad ke-20. Hal ini dikemukakan secara terang oleh Karel A. Steenbrink, bahwa pada era ini pendidikan Islam di Indonesia menuai klimaks. Apabila ditelisik, ini beriringan dengan berlangsungnya politik etis kolonial Belanda (Baca; Politik etis: irigasi, transmigrasi dan pendidikan). Perkembangan ini dipicu disebabkan salah satunya oleh dibukanya sekolah kolonial untuk para pribumi. Melihat hal ini, mendorong tokoh-tokoh Islam untuk mendirikan lembaga pendidikan Islam. Tidak hanya bertujuan untuk mendidik semata, tapi juga sebagai simbol dan gerakan perlawanan terhadap agenda pendidikan kolonial.

Di Sulawesi Selatan (Sulsel), lembaga lembaga pendidikan pesantren pada dasarnya telah ada bersamaan dengan diterima Islam sebagai agama di Kerajaan Gowa-Tallo pada tahun 1605 dinyatakan sebagai agama resmi kerajaan pada tanggal 9 November 1607 (Mattulada 1998, 193). Islam yang dibawa oleh trio datuk ini; Datuk Ri Bandang (Abdul Makmur), Datuk Patimang (Sulaiman), dan Datuk Ri Tiro (Abdul Jawad), menjadi menjadi fajar baru pendidikan Islam di kawasan. Selain itu, periode ini juga menjadi penanda dari permulaan berlangsungnya pendidikan Islam. Meskipun kala itu, pendidikan Islam masih sangat tebatas dan hanya bias diakses oleh keluarga kerajaan, namun perlahan terbukan untuk mayarakat pada umumnya. Ini dapat dilihat dari dibukanya pengajian Islam oleh Abdul Makmur atau Datuk Ri Bandang di Mesjid Kaluku Bodoa di Kerajaan Tallo. Terlebih lagi, kerajaan-kerajaan federasi diijinkan untuk mengirimkan perwakilannya untuk mempelajari Islam. 
Sayangnya, belum berlangsung lama kerajaan Gowa-Tallo diperhadapkan dengan perang melawan Belanda pada tahun 1660 hingga 1669 atau yang dikenal dengan "Perang Makassar". Kerajaan Gowa-Tallo mengalami kekalahan besar yang berimplikasi pada hancurnya struktur sosio-politik dan militer, serta lembaga pendidikan yang sedang berlangsung. Kendati demikian, pasca peristiwa besar tersebut proses pengajaran (pendidikan) Islam tidak sepenuhnya hilang. Ini dapat dilihat dibeberapa tempat proses tranformasi keilmuan Islam di Jazirah masih berlangsung, seperti; di Maros, Rappang, Tosora (Wajo), dan Mandar, meski tidak seperti sebelumnya.

Tidak seperti di pulau Jawa dan Sumatera, di Sulawesi Selatan pendidikan Islam mengalami stagnasi hingga tahun 1928 yang dtandai oleh datangnya Angregurutta Haji (AGH.) Muhammad As'ad. Ulama kelahiran Mekkah yang masih berdarah Bugis ini, kembali ke tanah leluhurnya, Wajo, mendidrikan sekolah Islam yang diberi nama, Madrasah Arabiyah Islamiyah (MAI) - tahun 1953 Madrasah Arabiyah Islamiah berubah nama menjadi Pesantren As'adiyah Sengkang. Lembaga ini pada gilirannya mencetak ulama-ulama besar di kawasan Indonesia Timur, dan menjadi geneologi pendidikan Islam kemudian. Hampir tidak satu pun lembaga pendidikan di Sulawesi Selatan yang berdiri setelahnya tanpa diinspirasi oleh lembaga ini. Oleh sebab itu, peneliti juga menyebut era ini sebagai titik balik sejarah perkembangan pendidikan Islam di daerah ini. Seperti misalnya, Pondok Pesantren (Ponpes) Darul Dakwah wal-Irsyad (DDI) Mangkoso yang didirikan oleh Anregurutta H. Ambo Dalle, Ponpes Al-Furqan yang didirikan oleh Anregurutta H. Muhammad Abduh Pabbajah, Ponpes Yasrib yang didirikan oleh Anregurutta H. Daud Ismail, Ponpes Darul Huffah yang didirikan oleh Anregurutta H. Lanre Said, dan masih banyak lagi, yang kesemuanya tidak lain adalah murid-murid Anregurutta Saade-sapaan Bugis Anregurutta H. Muhammad As'ad.

Berdasarkan data Kementerian Agama tahun 2008, hingga saat ini, tercatat sebanyak 227 pesantren di Sulawesi Selatan. Adapun data pemerintah Provinsi Sulawesi Selatan per tahun 2016, bahwa 
jumlah pesantren di wilayah ini berjumlah 240 unit. Bahkan, Abdul Rahman Halim (tt.), dalam penelitiannya, Implementasi Kebijakan pendidikan pada Madrasah Swasta di Sulawesi Selatan, mengemukakan bahwa jumlah madrasah baik negeri maupun swasta di tempat ini sebanyak 1.342. Dari jumlah ini terdapat 110 madrasah Negeri, yang meliputi; 46 madrasah Ibtidaiyah, 36 Tsanawiyah, dan 28 Aliayah, sedangkan Madrasah Swasta berjumlah 1.232, diantaranya; 588 madrasah Ibtidaiyah, 475 Tsanawiyah, dan 169 Aliyah. Apabila ditelisik lebih jauh, semua madarasah, baik dalam bentuk semi madrasah-pesantren maupun madrasah tanpa pesantren, lahir setelah berdirinya MAI.

Selain itu, belum ditemukan bentuk dan model pendidikan Islam formal dan cukup memadai sebelum hadirnya MAI. Kala itu, proses pengajaran masih dilakukan dalam bentuk langgar di rumahrumah guru, atau pengajian yang dilakukan di mesjid-mesjid. Namun, setelah MAI didirikan oleh Anregurutta, bentuk pengajaran pun berubah, yakni dalam bentuk langgar atau pengajian di Mesjid, dan kedua dalam bentuk sekolah berjenjang (kelas). Dengan format pendidikan baru inilah, pada gilirannya mengundang perhatian masyarakat seantero Sulawesi, khususnya orang-orang BugisMakassar, baik di tanah Sulawesi Selatan sendiri maupun di daerah migrasi mereka, untuk menitip anaknya didik ilmu agama di tempat ini. Dari para murid ini, setelah mereka pulang ke daerahnya masing-masing, tidak sedikit diantaranya mendidrikan pesantren. Itulah yang menjadi alasan peneliti juga menyebut MAI sebagai embrio pendidikan Islam di Sulawesi Selatan.

\section{Metode Penelitian}

Penelitian ini merupakan penelitian kepustakaan (research library) yang berpedoman pada metode penelitian kualitatif. Sumber data yang digunakan terdiri atas data primer dan data sekunder. Data primer yang dimaksud adalah data penelitian sebelumnya tentang pesantren As'adiyah Sengkang, dan dokumen-dokomen yang diperoleh melalui penelusuran peneliti di kantor pusat As'adiyah. 
Adapun data sekunder yang dimaksud adalah buku-buku dan dokumen-dokumen yang relevan dengan topik penelitian ini.

Dari yang diperoleh tersebut, kemudian dianalisis dengan menggunakan tiga unsur metodis: pertama, hermeneutika, yaitu; melakukan interpretasi terhadap teks-teks yang dibaca oleh peneliti, menelaah konteks sosio-kultural dan sosio-politik yang terjadi ketika itu, hingga menemukan benang merah gagasan modernisasi pesantren ditemukan; kedua, historis, yaitu melacak konteks historis baik dalam konteks agensi Anregurutta maupun latar belakang setting pemikiran As'adiyah; ketiga deskripsi, yaitu dari pembacaan tadi selanjutnya dideskripsikan dalam narasi yang utuh dan layak disajikan kepada pembaca.

\section{Konsep Modernisasi}

Menurut Ellya Rosana teoritisi modernisasi pertama kali menjadi diskursus akademik pada sekitar tahun 1950-an dan tahun 1960-an. Teori ini secara umum dipahami dalam tiga konteks: historis, relatif, dan analisis. Secara historis, modernisasi diartikan sama dengan westernisasi atau Amerikanisasi, yakni modernisasi dilihat sebagai gerakan menuju cita-cita masyarakat yang dijadikan model (Rosana 2011, 32). Sedangkang dalam pengertian relatif, modernisasi dipahami sebagai uapaya untuk menyamai standar yang dianggap modern baik oleh masyarakat banyak maupun oleh penguasa. Adapun dipahami sebagai analisis yakni melukiskan dimensi masyarakat moderen dengan maksud untuk ditanamkan dalam masyarakat tradisional atau masyarakat pra modern. Dari beragam pemahaman ini, modernisasi secara terang dapat dijelaskan sebagai suatu proses transformasi dari suatu arah perubahan ke arah yang lebih maju atau meningkat dalam berbagai aspek dalam kehidupan masyarakat. Secara sederhana dapat dikatakan bahwa modernisasi adalah proses perubahan dari caracara tradisional ke cara-cara baru yang lebih maju, dimana dimaksudkan untuk meningkatkan kesejahteraan masyarakat (Rosana 2011, 32-33). 


\section{Modernisasi Pendidikan Islam}

Modernisasi madrasah merupakan konsekuensi dari gagasan besar dalam modernisasi Islam. Menurur Charles Kurzman, bahwa salah satu karakter penting gerakan gerakan modernisasi Islam adalah muncul dan menguatnya kesadaran untuk mengadopsi nilainilai modern yang dikalangan muslim. Nilai modern yang dimaksud tersebut, antara lain: rasionalitas, sains, konstitusi, konsep-konsep baru tentang nilai-nilai egalitarian, dan sebagainya (Subhan 2012, 44). Kedua, yakni terkait dengan kesadaran untuk memanfaatkan dan memperkuat wacana keislaman yeng bersesuaian dengan konteks dunia modern saat ini.

Modernisasi madrasah merupakan pengambilan bentuk integrasi ilmu-ilmu umum modern ke dalam system pendidikan madrasah, introduksi motodologi pembejaran modern, dan adopsi terhadap fasilitas pendidikan modern. Menurut Arief Subhan setidaknya terdapat dua tipologi modernisasi pendidikan di Negaranegara Muslim; pertama, melakukan transformasi lembaga pendidikan tradisional seperti madrasah sehingga menjadi modern, terutama dengan memasukkan ilmu-ilmu umum modern dan transformasi kelembagaan; kedua, mendirikan lembaga pendidikan baru sebagai jalan untuk menaselerasi modernisasi (Subhan 2012, 45).

\section{Pendidikan Islam}

Menurut Ali Hasan dan Mukti Ali (2003: 45), menjelaskan bahwa Pendidikan Islam adalah pendidikan sejak pendirian dan penyelenggaraannya didorong oleh hasrat dan semangat cita-cita untuk mengejawantahkan nilai-nilai Islam, baik yang tercermin dalam nama lembaganya, maupun dalam kegiatan-kegiatan yang diselenggarakan. Pada konteks ini, Islam dimaksudkan sebagai sumber nilai yang diwujudkan dalam seluruh kegiatan pendidikan. Selain itu, pendidikan ini juga memberikan perhatian sekaligus menekankan ajaran Islam sebagai pengetahuan (Islam as knowledge). Islam pada sisi ini, dijadikan sebagai studi, baik bagi islam sendiri 
maupun bagi ilmu lain. Berikutnya, pendidikan islam dalam dua konteks sekaligus, yakni baik sebagai ilmu mapun sebagai nilai.

Pendidikan Islam secara kelembangaan setidaknya dapat dilihat dalam tiga bentuk; Pesantren Madrasah, dan sekolah islam terpadu. Pesantren atau pondok pesantren sebagaimana diterangkan oleh Zamakzary Dhofier (1994: 44), memuat setidaknya lima elemen pokok; pondok, masjid, santri, pengajaran kitab-kitab dan kiai. Sedangkan madrasah adalah hasil perkembangan modern dari pendidikan pesantren yang secara historis, jauh sebelum Belanda menjajah Indonesia, lembaga pendidikan Islam yang ada adalah pesantren yang memusatkan kegiatannya untuk mendidik para santrinya mendalami ilmu agama. Madrasah merupakan desain umat Islam yang berkeinginan untuk mempermodern lembaga pendidikan mereka (Akhwan 2008, 41). Perbedaan madrasah dengan pesantren menurut Furchan dalam Akhwan terletak pada sistem pendidikannya (Akhwan 2008, 43). Madrasah menganut sistem pendidikan formal (dengan kurikulum nasional, pemberian pelajaran dan ujian yang terjadual, bangku dan papan tulis seperti umumnya sekolah model Barat) sedangkan pesantren menganut sistem non-formal (dengan kurikulum yang sangat bersifat lokal, pemberian pelajaran yang tidak seragam, sering tanpa ujian untuk mengukur keberhasilan belajar siswa). Namun demikian, perlu diketahui pula bahwa, tidak sedikit saat ini yang menggabungkan antara madarasah dan pesantren; dalam pesantren terdapat madrasah, atau pesantren membentuk sekolah formal di dalamnya. Tujuannya, tentu saja untuk menjawab persoalan saat ini.

Adapun sekolah yakni sekolah islam terpadu atau umum (menitik beratkan pada pelajaran umum), namun salah satu objek bahasan yang dianggap penting dalam pembelajarannya adalah pendidikan agama. Pelaksanaan pendidikan Islam di sekolah umum pada dasarnya adalah amanah sejak adanya rapat Badan Komite Nasional Indonesia Pusat (BPKNIP) (Daulay 2012, 38). Jika mengacu pada UU No. 20 tahun 2003 tentang Sistem Pendidikan Nasional, setidaknya terdapat tiga yang dimaksudkan sebagai pendidikan Islam :1) secara kelembagaan, kelembagaan ini 
berbentuk madrasah, Pesantren Diniyah Raudatul Atfal sebagai lembaga yang diakui yang setara dengan sekolah; 2) pendidikan Islam sebagai mata pelajaran yakni pelajaran agama Islam di sekolah dan madrasah; 3) nilai (value) atau perangkat nilai Islam dalam system pendidikan nasional (Daulay 2012, 38).

\section{Setting Pendidikan Islam Sebelum abad ke 20}

Islamisasi di Sulawesi Selatan ditandai oleh diterimanya Islam oleh Raja Gowa ke-14, I Manggaranggi Daeng Manrabia Sultan Alauddin. Di depan Abdul Makmur Datuk Ri Bandang Sang Raja melafazkan dua kalimat syahadat. Namun perlu diketahui pula bahwa, sebelumnya Raja Tallo, I Mallingkang Daeng Mannyonri' Sultan Abdullah Awalul Islam sekaligus Mangkubumi (Perdana Menteri) Kerajaan Gowa lebih dahulu menerima menerimanya. Penerimaan ini berimplikasi pada penerimaan rakyat Gowa atas ajaran baru tersebut. Seperti yang diterangkan oleh Mattulada, seorang sejarawan Bugis dan Guru Besar Antopologi Unhas, bahwa Islam diterima sebagai agama resmi di Butta (tanah) Gowa pada tangal 9 november 1607, dan diikuti seluruh rakyat kala itu. Sejak saat itu maka tuntutan untuk belajar tentang Islam semakin kuat, baik oleh masyarakat umum mapun para bangsawan kerajaan Gowa. Lebih lanjut, Mattulada menulis:

Abdul Makmur Khatib Tungga (Datuk Ri Bandang), menjadi ulama yang mengajarkan agama itu dikalangan kaum bangsawan dan pembesar kerajaan. Didirikannya masjid di Kaluku-Bodoa-Tallo, menjadi pusat pengajian Islam.Pusat Pengajian pertama itu (Kaluku-Bodoa-Tallo) ramai dikunjungi oleh murid-murid yang bersal dari Butta Gowa dan negerinegeri lainya yang telah menerima Islam. Pokok-pokok ajaran Islam yang dikembangkan di Pusat pengajian Kaluku-Bodoa, adalah syariat Islam, yang bersaran pada rukun Islam, rukun Iman, tentang hukum-hukum wajib, harus, makruh, mubah dan haram; tentang hokum perkawinan, pewarisan dan upacara-upacara hari besar Islam. (Mattulada 1995, 193)

Dalam perkembangannya kemudian pendidikan Islam KalukuBodoa dari hari ke hari semakin berkembang. Pada era Kepemimpinan Sultan Malikul-Said, I Manuntungi daeng Mottola Karaeng Laikung semakin dilebarkanlah pengajaran-pengajaran 
pendidikan Islam di wilayah negeri-negeri Bate Salapang (Sembilan Kerajaan yang menjadi penyangga kerajaan Gowa).Di setiap negeri Bate ini didirikan masjid dan langgar, yang selain digunakan untuk beribadah juga digunakan sebagai tempat pengajian pendidikan agama, khususnya bagi anak-anak.Orang yang membina pendidikan ini kemudian di sebut dengan Arong-Gurunta atau Gurutta.

Ketika itu pengajaran yang diberikan tidak saja tentang baca tulis al-Quran, tapi bagaimana masyarakat dapat memahami ajaran Islam secara benar.Mengenai buku rujukan yang banyak digunakan ialah buku berbahasa Melayu dan Arab.Khusus untuk yang berbahasa Melayu, orang Makassar telah banyak mengetahuinya.Karena banyak orang melayu yang bermukim di Makassar ketika itu.Bahkan "notulen" kerajaan adalah seorang melayu. Selain itu surat menyurat antara kerajaan juga menggunakan bahasa Melayu. Di Makassar sendiri, masyarakat memiliki aksara yang di sebut dengan Lontara'.Sehingga kemudian banyak buku-buku yang dijadikan acuan pelajaran Islam yang berbahasa Melayu di alihbahasakan dan disalin kembali ke dalam lontara'.

Berbagai Lontara yang berasal dari naskah berbahasa Melayu yang dijadikan acuan dalam kurikulum pembelajaran, yang bahkan hari ini masih bisa ditemukan, antara lain (Mattulada 1995, 194);

1) Lontara' perkawinan antara Saidina Ali dengan Fatimah, Puteri Rasulullah

2) Lontara' nabi Yusuf dan Percintaan Laila Majnun

3) Sura' Bukkuru', dalam bahasa Bugis dikenal dengan Lontara' pau-paunna Sultail Injilai;

4) Budi Istikhara

5) Kitta’ Parai' (hokum Kewarisan Islam)

6) Kitta' Nikeka

7) Lontara' Sehe-Maradang

8) Lontara' tentang peperangan nabi Muham mad dengan Raja Hindi

9) Berbagai mukjizan nabi Muhammad

10) Lontara' tentang wewenang Kadhi, menurut Syariat Islam. 
Buku-buku ini diduga berasal dari zaman permualaan agama Islam di Sulawesi selatan abad 17) yang sampai saat ini masih popular dalam kalangan orang tua Bugis-Makassar,

Pada masa pemerintahan Raja Gowa ke 15, I manuntungi Daeng Mattola Karaeng Laikung, yang bergelar Sultan Malikul-Said dan berkuasa dari 1637-1653 M, memperluas ekses pendidikan kepada daerah-daerah kekuasaanya, yaitu batesalapang (Sembilan kerajaan). Melalui titahnya, didirikanlah masjid-masjid dan langgarlanggar di setiap negeri Bate.Masjid dan langgar ini kemudian dijadikan sebagai tempata ibadah dan pendidikan agama Islam untuk anak-anak muda di daerah itu.Bahkan menurut Mattulada, pendidikan Islam, berupa baca tulis Al-Quran menjadi Wajib bagi semua masyarakat yang telah mengkalim diri sebagai orang Islam.

Salah seorang yang belajar pada langgar ini, kelak di kenal sebagai ulama besar, yaitu Syekh Yusuf Al-Makassari. Pada usianya yang kedelapan belas tahun, tepat 22 September 1645, ia berangkat ke Mekkah untuk belajar. Setelah belajar pada banyak ulama dan bermukim bertahun-tahun di sana, Ia kemudian kembali kekampung halamannya untuk mengembangkan pendidikan Islam. Namun ia sangat kecewa, karena ajaran Islam telah bercampur dengan kemaksiatan dan syariat Islam menjadi diabaikan. Oleh karena itu, ia kemudian melanjutkan pengembaraannya menuju Banten. Di Banten ia disambut baik dan di berikan kewenangan untuk mengajar di sana. Namun sebelum Syak Yusuf berangkat meningalkan negerinya, Ia sempat menamatkan dan memberi Ijazah kepada murid-muridnya ang terkemuka, yaitu Syekh Nuruddin Abdul Fatah, Abdul Basyir Adlarir ar-Raffani (dari Rappang) dan Abdul Kadir Karaeng Jero. Kepada murinya ini, kekuasaan diberikan untuk melanjutkan pengembangan dan pendidikan Islam di Sulawesi Selatan. (Mattulada 1995, 197).

Sekutu dan mitra kerajaan Gowa Kerajaan ketika itu ialah kejaraan Wajo. Sehingga setelah kerajaan Gowa menerima Islam, maka selanjutnya ia Datuk Sulaiman atau Datuk Patimang di utus oleh Raja Gowa ke 14, Sultan Alauddin, untuk mengislamkan kerajaan ini dan mengajarkan Islam di sana. Islam pertama kali di 
terima oleh kerajaan Wajo tepat pada hari selasa tanggal 15 syafar $1020 \mathrm{H}$ atau $1610 \mathrm{M}$ oleh Arung MatoaWajo ke 12, La sangkuru Mulajaji (Mattulada 1995, 202).

Menurut Mattulada ada dua model pendidikan yang dilaksanakan ketika itu, yakni;

Pertama, untuk pendidikan dasar agama (mengaji Quran), belajar shalat dan lali-lain bagi anak.Mereka mengunjungi guru mengaji dan dilakukan di masjid-mesjid atau di rumah-rumah mengaji itu. Guru-guru mengaji itu pada umumnya adalah juga parewa sara', yaitu Imam, Khatib dan lainlain. kedua, untum mendidik pemuda-pemuda dengan ilmu yang lebih tinggi, pemuda-pemuda itu mengunjungi ulama-ulama tertentu yang memberikan pendidikan lanjutan. Di tempat kediaman ulama itu berkumpullah puluhan pemuda "santari" untuk mengikuti pengajian.Metode pengajian itu di kenal dengan istilah "panggaji kitta". Di tempat-tempat terkenal, para santri ada kalanya berasal dari negeri lain di luar Sulaw esi Selatan (201).

Seturut dengan Mattulada, Cristian Pelras, seorang peneliti Prancis, juga mengemukakan hal yang sama. Menurutnya, pendidikan agama secara tradisional di mulai sejak kanak-kanak, usia sekitar 5 atau 6 tahun, baik laki-laki mapun perempuan (Pelras 2006, 215-216). Pada tahap ini, ana-anak diajarkan untuk membaca Al-Quran, dimulai dari Juz Amma (Juz ke 30) yang di sebut dalam dengan "Al-Quran Kecil". Ketika telah menamatkan dan dianggap oleh gurunya suda dapat membaca dan lancar, maka selanjutnya ia perkenangkan untuk belajar membaca "Al-Quran Besar" yang terdiri dari Juz 1 sampai Juz ke 30. Selain itu mereka juga di ajarkan untuk belajar tata cara shalat, adat sopan santun dan dianjurkan untuk menhafal beberapa surat-surat pendek. Setelah menamatkan Al-Quran, maka pada tahap selanjutnya, yaitu mengaji kitab di bawah bimbingan seorang guru pada "sekolah pengajian". Istilah ini dikenal dalam bahasa Bugis dengan anggajing. Model belajar yang demikian ini di Jawa di sebut pesantren atau pondok, di Sumatera di sebut surau dan Aceh di sebut rangkang. Mula-mula mereka belajar Nabwu dan Syaraf serta dasar-dasar hokum Islam, kemudian dilanjutkan dengan pelajaran lainnya yang dianggap lebih tinggi oleh Guru yang mengajarnya, seperi Ilmu Fikih, ilmu Aqidah, tafsir al-Quran, dan bahkan tasawwuf. Sisitem berlangsung hingga akhir 
abad ke 20.Beberapa titik sentral pendidikan Islam ketika itu di Sulawesi Selatan, ialah seperti di Maros, Pangkaje'ne (termasuk pulau Salemo), dan sekitar Rappang.

\section{Pendidikan Islam Di Sulawesi Selatan adab ke 20.}

Pada abad ke 20 di Sulawesi Selatan terjadi titik balik pembaruan pendidikan Islam yang diikuti oleh pergeseran paradigma masyarakat tentang Islam. Tentu saja ini tidak dapat dilihat secara parsial, karena seperti diketahui, suatu perubahan tidak pernah terjadi begitu saja, akan tetapi disebabkan oleh beberapa faktor. Di antara faktor-faktor itu ialah; ide dan gagasan yang di usung, kefiguran seorang tokoh, manajemen, dan bentuk organisasi pendidikannya. Namun dalam pembahasan ini, penulis tidak akan menguraikan secara detail dan panjang lebar faktorfaktor tersebut, karena tulisan ini hanya merupakan pelengkap dari pembahasan malakah yang pernah penulis paparkan dalam presentasi kelas sebelumnya. Oleh Karena itu, sebagai tulisan pelengkap, maka pada tulisan ini hanya akan menyajikan paling tidak dua poin utama untuk melihat secara lebih jelas pembaruan tersebut, yaitu; bagaimana pendidikan Islam sebelum abad ke 20 di Sulawesi Selatan dan apa pembaruan dilakukan ketika itu, khususnya gagasan yang ditawarkan (kurikulum pendidikannya).

\section{AGH. Muhammad As'ad: Figur Pembaru Pendidikan Islam}

AGH. Muhammad As'ad, lahir di Mekkah tepat pada tanggal 12 rabiulawal 1326 H, bertepatan dengan 14 April 1907 M. Ia adalah anak kedelapan dari Sembilan bersaudara. Sejak kecil ia menghabiskan waktunya di kota Suci Mekah bersama kedua keluarga besarnya. Meskipun secara genetal, ia berdarah Bugis, namun hingga usinya yang ke 21 tahun ia tidak pernah menginjakkan kakinya di tanah Bugis. Karena sejak kakeknya, Syekh Abd. Rahman, datang ke kota Mekkah dan berdomisili di sana, ia tidak pernah lagi kembali ke tanah airnya. Ini merupakan bagian dari kebiasaan orang Bugis pada masa lampau dan masih berlaku sampai hari ini, yaitu kegemaran merantau untuk menuntut 
ilmu pengetahuan, berdagang atau berhijrah dari daerah yang tidak aman ke daerah yang aman dengan membawa keluarga (Dahlan 2013, 69).

Kedatangan keluarga Muhammad As'ad ke Mekkah bukan hanya persoalan keamanan tapi, kenginan yang kuat untuk belajar dan memperdalam ilmu agama (Islam). Bahaking Rama, seperti yang dikutip dalam Matsuki H.S dan M. Ishom el-Saha (ed.), bahwa alasan kepergian orang tuanya (termasuk juga kakek-neneknya) ke Mekkah dan kemudian menetap di sana, menurutnya, di samping menunaikan haji, mereka juga meninggalkan Wajo karena menghindari kerusuhan yang terjadi di daerah tersebut(Matsuki HS dan al-Saha 2006, 279).

Muhammad As'ad kecil mendapat pendidikan dasar dari orang tuanya, H. Abd.Rasyid.Ia mula-mula belajar membaca al-Quran dan dasar-dasar pengetahuan keislaman (Matsuki HS dan al-Saha 2006, 279). Selain itu, ia juga diajarkan oleh orang tuanya bahasa dan budaya Bugis sejak kecil termasuk diperkenalkan padanya aksara Lontara' Bugis. Pada usianya yang ke 14 tahun As'ad telah dinyatakan lulus dalam menghafal al-Quran. Dengan petunjuk dari orang tuanya, pada usia ini juga, ia kemudian melanjutkan pendidikanya Madrasah al-Falah yang berlokasi dekat dengan Mesjid al-Haram. Madrasah ini merupakan lembaga pendidikan yang didirikan oleh orang India, setelah menyadari keterbelakangan umat Islam di bidang ilmu pengetahuan umum. Oleh kerena di madrasah ini, selain diajarkan pengetahuan agama, juga diajarkan kepada murid-muridnya pengetahuan umum seperti: ilmu bumi (Geografi), ilmu hayat (terdiri dari: ilmu tubuh manusia, ilmu tumbuh-tumbuhan, dan ilmu hewan), ilmu alam, ilmu kimia dan ilmu fisika (Dahlan 2013, 73).

Keilmuan As'ad terbilang komprehensif, karena dipengaruhi oleh banyak guru, baik bada bidang agama mapun ilmu-ilmu lain. Menurut Ahmad Rahman, ia belajar dengan mendatangi ulamaulama besar untuk berguru setiap hari. Ada 14 mata pelajaran yang diperoleh dalam sehari semalam dari para alama ini, baik ulama Arab maupun ulama Indonesi itu sendiri (Dahlan 2013, 85). Di 
antara mereka ialah; Syekh Umar Hamdani al-Magrib, Syekh Jamal al-Maliki, Syekh Said al-Yamani, Syekh Hasan al-Yamani, Syekh Ahmad Nasyirin, Syekh Abrar, Sayyid Ahmad Syarif al-Sanusi, Syekh Abd. Rasyid al-Bugisi (Ayah As'ad), Syekh Mallawa al-Bugisi, Syekh Abbas Abd.Jabbar al-Bugisi, dan Syekh Ambo Wellan alBugisi.

Pada usinya yang ke 21 tahun, tepat pada 1347 atau bulan desember 1928, AGH. Muahammad As'ad, berangkat meninggalkan tanah kelahirannya Mekkah menuju tanah kelahiran nenek moyannya di Wajo Sulawesi Selatan Indonesia (Dahlan 2013, 85). Kedatangannya sebagai tuntutan moral untuk menyampaikan syiar Islam dan memperbaiki pendidikan yang ada di Wajo dan Wanua Sempugi- Wanua Sempugi pertama kali digunakan ketika Arung Palakka setelah menaklukkan Imperium Gowa pada abad ke 17(Sulawesi Selatan) secara umum.

\section{Wajah Baru Pendidikan Islam di Sulawesi Selatan}

Meskipun pada permulaan telah terjadi golombang besar terhadap pendidikan di Jawa melalui politik etis yang diberlakukan oleh Belanda, namun tidak demikian halnya di Sulawesi Selatan.Selain disebabkan oleh jumlah sekolah yang disediakan yang sangat terbatas dan hanya ada di Makassar, para bangsawan dan tokoh-masyarakat enggan menyokolahkan anaknya di sekolah Belanda. Mereka menganggap dengan bersokolah di sekolah Belanda, anak mereka akan "di-belanda-kan". Menurut Mattulada (1998: 479), dalam bukunya, Latoa, menjelaskan bahwa; sampai pada saat sebelum perang Dunia II, yaitu, untuk pendidikan anakanak pemukan masyarakat Bugis Makassar di Sulawesi selatan hanya tersedia sebuah AMS (Algemene Middelbare School), Sebuah sekolah menegah pertama (MULO), sebuah sekolah Pamong-Praja (CIBA dan OSVIA), sebuah HIK dan Normaal School (Sekolah Guru), semuanya didirikan di dalam kota Makassar guna menampung anak-anak para pemuka masyarakat bumi-putera dari segenap wilayah Timur Indonesia dan Kalimantan (Grote Oost). Oleh karena itu, masyarakat lebih memilih menyokolahkan anaknya 
di sekolah-sekolah agama yang ada di daerah-daerah mereka.Jika pun mereka menginginkan pengetahuan yang lebih, para orang tua tidak segan-segan untuk mengirim anak-anak mereka di tempattempat yang dianggap sebagai lumbung pengetahuan agama, seperti, di Rappang Sidrap, Maros, Pulau Salemo Pangkep, dan juga di Polman (sekarang telah menjadi Wilayah Sulawesi Barat).

Karel A. Streenbrink (1994: 26-28), menjelaskan bahwa pada permulaan abad ke 20, pendidikan Islam di Indonesia, dan termasuk juga di Sulawesi Selatan, memasuki era baru. Bahkan dikatakan koherensi logis dengan masa sebelumnya menjadi tidak dapat dijadikan acuan. Seperti kehidupan lain pada umumnya perkembangan Islam juga tidak dapat diramalkan secara pasti sebelumnya dan kadang-kadang dalam pengamatan pertama menurut sistematika umum, perkembangan tersebut tidak begitu logis.

Di Sulawesi Selatan sendiri paling tidak ada dua tokoh yang memegang pengaruh kunci dalam pembaharuan pendidikan Islam, yaitu, AGH. Abdullah Dahlan bin Abdurrahman dan AGH. Muhammad As'ad. Kedua tokoh ini masing-masing pernah belajar di Mekkah, dan kembali kampung halaman mereka untuk memperbaiki Islam. Abdullah Dahlan, setelah belajar di Mekkah dari Tahun 1907 sampai 1917 dan kembali ke Sulawesi Selatan, ia mendirikan organisasi bernama As-Sirath al-Mustaqim pada tahun 1923. Pada tahun 1926, kelompok ini bergabung dengan Muhammadiyah. Cabang Muhammadiyah pertama di Luar kota Makassar adalah terbentuk di Wajo, tahun 1928 (Gibson 2012, 193-194). Pada tempat dan tahun yang bersamaan, AGH.Muhammad As'ad pun tiba dari tanah kelahirannya Mekkah.Meskipun Muhammadiyah sejak didirikannya pada tahun 1926 sampai 1933, telah berdiri 16 cabang di Sulawesi Selatan, kurang mendapat respon dari elit-elit setempat. Berbeda dengan AGH. As'ad, dapat bergandengan tangan dengan elite lokal.Ini terlihat dari hadiah berupa rumah yang diberikan oleh Arung Matowa Wajo Andi Mangkona kepadanya. 
Sejak kedatangnya di Wajo, AGH. Muhammad As'ad, mendapat sambutang hangat dari masyarakat setempat, terlebih oleh Arung Matowa Wajo. Setibanya di tempat ini, ia mulanya tingal sementara di rumah iparnya Haji Sahabuddin (w. 1943) yang dikenal dengan haji Emme (strinya bernama Haji Sitti, yang tidak lain ialah saudara Muhammad As'ad) (Dahlan 2013, xxviii). Ambo Emme adalah ulama yang menggantikan Haji Singkang (w. 1916), yang memiliki banyak murid dan berdatangan di luar Wajo. Namun setelah kedatangan As'ad, ia kemudian menggantikan iparnya meneruskan pengajian. Namun dari hari ke hari orang-orang semakin berdatangan dari berbagai pelosok daerah, sehingga kapasitas rumah pengajian tidak memungkinkan lagi.Sehingga pengajian ini kemudian dipindahkan ke masjid Jami Sengkang, dan pada tahun 1930, di bentuklah Madrasah Arabiyah Islamiyah (MAI).Dari madrasah inilah lahir geneologi ulama di Sulawesi Selatan, dan Indonesia bagian Timur secara umum.Dapat dikatan bahwa hampir semua ulama Sulawesi selatan pada abad ke 20, merupakan alumni atau paling tidak pernah belajar di MAI.

Jika sebelumnya lembaga lembaga pendidikan Islam belum mendapat bentuknya, termasuk proses belajar mengajar dilakukan sesuai persetujuan gurunya, maka pada pada periode ini pendidikan lebih terorganisir dan sitematis. Sistem penjenjangan kelas dan waktu belajar pun mulai diberlakukan.Selain itu, metode belajar yang digunakan bersifat dialetis.Karena beberapa metode selain metode ceramah yang digunakan misalnya, Tanya-jawab, diskusi serta pemberian tugas kepada murid-murid (Dahlan 2013, xxviii).

Pendidikan yang dilaksanakan oleh AGH.Muhammad As'ad adalah suatu model yang beruhasa menggabungkan antara sistem pendidikan pesantren dengan sistem pendidikan madrasah. Berbekal model pendidikan yang dilaluinya baik di kelolah oleh ayahnya, Abd. Rasyid muapun sekolahnya di madrasah Al-Falah, ia kemudian mengembangkannya menjadi empat jenjang, yaitu; jenjang Ibtidaiyah, Tsanawiyah, Tahridiyah, dan Aliyah. Selain itu, ia juga menyiapkan kelas khusus untuk pengkaderan ulama. 
Mengenai periode dan pelajaran pada masing-masing tingkatan dapat dijelaskan sebagai berikut (Dahlan 2013, 149-150):

\section{Tahap Ibtidaiyah.}

Pada tahap ini lama bejarnya 4 tahun.Pelajaran yang diberikan semuanya menggunkan pengantar bahasa Arab.Bahasa Arab ini digunakan juga dalam percakapan sehari-hari dalam lingkungan pesantren ataupu diluar lingkungan pesantren, sehingga menjadi bahasa kedua yang dikuasai oleh santri sesudah bahasa Bugis.

\section{Tahap Tsanawiyah}

Pada tingkat ini lama belajar ialah 3 tahun. Santri dinyatakan lulus boleh melanjutkan pendidikanya ke tingkat Tsanawiyah, terutama mereka yang mahir menggunkan bahsa Arab dan telah di akui oleh oleh AGH. Muhammad As'ad. Mata pelajaran pada tingkat Tsanawiyah adalah Tafsir, Hadis, Fiqih, Ushul Fiqih, Tauhid, Nahwu, Sharf, Bayan dan Ilmu Mantid, dengan Praktik pidato dalam bahasa Arab yang di adakan sekali dalam sepekan. Selain itu, Murid yang pada tingkat ini yang terpilih oleh AGH.Mummad As'ad diberi tugas untuk mengajar di Tingkat Ibtidaiyah.

\section{Tahap Tabridiyah.}

Yaitu, tingkatan kelas persiapan untuk meyakinkan bahwa santri tersebut benar-benar siap mental dan telah menguasai bahasa arab dengan segala seluk beluknya. Lama belajar pada tahap ini ialah satu tahun.

\section{Aliyah}

Yaitu, dengan lama belajarnya 3 tahun.Pada tingkat ini para santri mendalami ilmu-ilmu yang telah diberikan ketika masih berada di jenjang Tsanawiyah.Selain itu, pelajaran tambahan yang lainnya ialah pelajaran Ahklak, Ilmu Faraidh, dan Ilmu 'Arudh.Pada ini pula diberi pula pelajaran tambahan seperti; ilmu bumi, ilmu hayat, ilmu alam, ilmu Handasah (Al-jabar dan Ilmu Ukur) dan ilmu 
geografi.Sedangkan pada kelas yang terakhir, ialah kelas khusus yang bersifat non-formal.Kelas ini merupakan kelas pengkaderan ulama.Mengenai batas waktu belajarnya pun tidak ditentukan. Santri yang telah lulus pada tahap yang terakhir ini akan diberikan izin untuk mendirikan cabang di daerah mereka masing-masing.

Penjelasan lebih lanjut mengenai kurikulum MAI disesuaikan masing-masing tingkatan ini lakukan berdasarkan klasifikasi umur.Hanya saja penulis pada tahap yang lebih rijid belum menemukan data tentang kurikulum pada masing-masing level.Akan tetapi, kurikulum MAI secara garis besar dapat ditemukan dalam penelitian Sitti Salmiah. Menurutnya, kurikulum MAI dibagi menjadi dua bagian yaitu; Kurikulum Inti dan kurukulum tambahan (Dahlan 2013, 261).

Kurikulum inti terdiri dari mata pelajaran:

1) Ilmu Tafsir, 2) Ilmu Hadis, 3) Ilmu Fiqh, 4) Ilmu Ushul Fiqh, 5) Ilmu Tauhid, 6) Ilmu Nahwu, 7) Ilmu Sharf, 8) Ilmu Ma’ani, 9) Ilmu Balaghah, 10) Ilmu Bayan, 11) Ilmu Mantiq.

2) Sedangkan Kurikulum Tambahan, yang tediri dari dua kelompok pelajaran, yaitu: Mata pelajaran yang bersifat agama dan mata pelajaran yang bersifat umum. Mata Pelajaran Tambahan Yang bersifat Agama, yaitu: 1) Ilmu Ahklaq, 2) Ilmu Faraid, 3) Ilmu 'Arudh, 4) Ilmu Dakwa, 5) Praktek Dakwah. Mata pelajaran tambahan yang bersifat umum, yaitu; 1) Ilmu Bumi, 2) Ilmu Hayat, 3) Ilmu Alam, 4) Ilmu Handasah, 5) Ilmu Geografi.

Dari sini, maka semakin jelaslah kurikulum yang diterapkan dalam pembaruan Pendidikan Islam yang dilakukan oleh AGH. Muhammad As'ad. Selain itu, dari aspek oraganisasinya, masingmasing oaring mendapatkan tugasnya secara sendiri, mulai dari pembagian jam mengajar, pelajaran yang diajarkan, dan bahkan sampai pada pembagian tugas administrasi.Sehingga bukan sesuatu yang berlebihan jika pada periode ini disebut sebagai titik balik pendidikan Islam di Sulawesi Selatan.Karena tidak hanya itu, murid-murid MAI, khususnya murid-murid Awal, setelah belajar di tempat ini dan mendapat restu dari gurunya, Muhammad As'ad, 
mereka pun mendirikan lembaga pendidikan Islam di daerahnya masing-masing. Misalnya, AGH. Abdul Rahman Ambo Dalle yang mendirikan DDI Mangkoso di Barru, AGH.Daud Ismail mendirikan Pesantren Yastrib di Soppeng, AGH.Pabbaja mendirikan Pesantren Al-Furqan Di Pare-Pare, AGH. Muhammad Said Tahfiz di mendirikan Pesantren 77 di Bone, AGH. Haruna Rasyid di Sidrap, dll.

Darul Da'wah wal Irsyad (DDI) sendiri dirintis oleh AGH.Abdul Rahman Ambo Dalle adalah salah satu lembaga pendidikan di Sulawesi Selatan yang hingga hari memilki cabang di berbagai daerah. Menurut Mattulada, pada mulanya di Mangkoso (sekarang masuk wilayah kabupaten Barru) masyarakat berkeinginan mendirikan Madrasah Arabiyah Islamiyah (MAI) di daerahnya. Pada tahun 1932 setelah H.M. Yusuf Andi Dagong menjadi Arung (Raja) di Kerajaan (Swapraja) Soppeng Riaja menggantikan kakaknya H. A. Maddiaewe Petta Lawawu, yang mengundurkan diri karena sakit-sakitan. Memang H.M. Yusuf Andi Dagong Pantas menjadi raja, karena sebelumnya juga menjadi Petta Pabbicara di kerjaan Barru.Ketika menjadi Arung, Beliau dipanggil dengan petta gelaran Petta Soppeng. Tahun 1953, di awal pemerintahannya di Barru di Bangunlah tiga mensjid masing-masing di Lapasu, Mangkoso, dan Takalasi. Namun kondisi masjid yang dibangun di wilayah kerajaannya ternyata jamaahnya kecil, baik untuk shalat lima waktu maupun shalat jum'at (Bekti dan Mallongi 2010, 297).

Keresahan ini selanjutnya direspon oleh penguasa dan tokoh masyarakat untuk dapat berembuk dan musyawarah bersama. Acara rembuk suara ini di sebut dengan tudang sipulung yang dilaksanakan di Saoraja, rumah kediaman Raja. Di antara tokoh masyarakat yang hadiri antara lain; Petta Coa, Petta Lawallu, Puang Mangung, Petta Sullewetang (A. Sanang), Petta Pabbicara (A. Renreng) Puang Huseng, Haji Kitta' (Kadhi Soppeng Riaja), seluruh imam dan kepala kampong (Bekti dan Mallongi 2010, 297). Selain itu, hadir juga Syekh Mahdar (seorang Ulama Arab dari Gorontalo yang beristri orang Mangkoso) dan Petta Soppeng sendiri sebagai inisiator.Dari pertemuan ini, maka muncullah ususlan dari Syekh 
Mahdar untuk mendirikan lembaga pendidikan sebagai usaha untuk memberi pemahaman agama kepada masyarakat, sehingga mereka dapat tertarik ke masjid.Dari padanya kemudian didirikanlah Darul Dakwah wal Irsyad (DDI).

Meskipun dalam lintas sejarah, pendidikan Islam menjadi bagian inheren dalam proses berbudaya di Sulawesi Selatan, namun demikian baru pada sekitar abad ke Akhir 20 barulah pendidikan Islam mendapat perhatian. Alih-alih pesantren sebagai suatu lembaga pendidikan Islam yang telah menjadi penyangga bagi terciptanya masyarakat yang baik sejak dahulu, justru dalam perkembangannya tidak mendapat perhatian yang memadai dari pemerintah.Sebagai alasannya, pendidikan Islam secara struktur lembaga pendidikan ini tidak masuk dalam struktur secara kelembagaan kementerian Pendidikan dan kebudayaan.Seperti misalnya, Yayasan pendidikan Swasta Muhammadiyah, Darul Da'wa wal Irsyad (DDI), As'adiyah, dan perguruan Islam lainnya.

\section{Catatan Akhir}

Pembahasan tentang pembaruan dan pengembangan pendidikan Islam di Sulawesi selatan abad ke 20 melukiskan gambaran islamisasi yang sesungguhnya di tempat ini.Gelombang yang terjadi ketika itu sungguh menjadi titik balik dari keberislaman masyarakat sesungguhnya. Meskipun secara formal Islam telah di terima sejak pengislaman Raja Gowa ke- 17 oleh Sultan Alauddin, namun ketika pengislaman tidak begitu signifikan merubah masyarakat. Barulah setelah abad ke 20 melalui kedatangan AGH.Muhammad As'ad membawa angin sejuk Islam di wilayah ini.

Keberadaan Madrasan Arabiyah Islamiyah (MAI) yang didirikan oleh AGH. Muhammad As'ad, merupakan embrio pesantren dan ulama di Sulawesi Selatan secara massif. Selama satu abad lembaga pendidikan ini menjadi penyangga tercipnya basis sumber daya manusia yang bernafas Islam. Bukan hanya itu, wajah baru pendidikan Islam di tempat ini pun pada akhirnya telah menemui bentuknya.Sehingga bukan suatu yang mengherangkan jika ulama- 
ulama besar Sulawesi Selatan ketika itu dan bahkan hari ini lahir dari rahim lembaga pendidikan ini.

\section{Daftar Pustaka}

Akhwan, Muzhoffar. 2008. "Pengembangan Madrasah Sebagai Pendidikan Untuk Semua." eL Tarbawi 1 (1): 41-54. https://doi.org/10.20885/tarbawi.vol1.iss1.art4.

Bekti, Andi Faisal, dan Tonang Mallongi. 2010. "Bugis dan Islam: Kontribusi DDI dalam Pengembangan Islam di Nusantara." In Diaspora Bugis di Alam Melayu Nusantara, diedit oleh Andi Faisal Bekti. Makassar: Inninawa.

Dahlan, Sitti Salmiah. 2013. Riblah Ilmiah AGH. Mubammad As'ad dari Haramain ke Wajo Celebes: Sebuah Perjalanan Religi Untuk. Membangun Madrasah Arabiyah Islamiyah di Wajo Bugis Makassar. Jakarta: Rabbani Press.

Daulay, Haidar Putra. 2012. Pendidikan Islam dalam Sistem Pendidikan Nasional. Jakarta: Kencana Press.

Dhofier, Zamakhsyari. 1994. Tradisi Pesantren: Studi tentang Pandangan Hidup Kyai. Jakarta: LP3ES.

Gibson, Thomas. 2012. Narasi Islam dan Otoritas di Asia Tenggara: Abad ke-16 hingga Abad ke 21. Diterjemahkan oleh Nurhady Sirimorok. Makassar: Inninawa.

Hasan, Ali, dan Mukti Ali. 2003. Kapita Selekta Pendidikan Agama Islam. Jakarta: Pedoman Ilmu Jaya.

Matsuki HS, dan M. Ishom al-Saha. 2006. Intelektualisme Pesantren: Potret Tokoh dan Cakrawala Pemikiran di Era Perkembangan Pesantren. Jakarta: Diva Pustaka.

Mattulada, Latoa. 1995. Suatu Lukisan Analisis Terhadap Antropologi Politik Orang Bugis. Makassar: Hasanuddin University Press. 1998. Sejarah, Masyarakat dan Kebudayaan di Sulawesi Selatan. Makassar: Hasanuddin University Press.

Pelras, Cristian. 2006. Manusia Bugis (The Bugis). Jakarta: Nalar \& Forum Jakarta-Paris EFEO.

Rosana, Ellaya. 2011. "Modernisasi dan Perubahan Sosial." TAPIs 7 (12). 
el-HiKMAH, Vol. 12, No. 1, Juni 2018

Steenbrink, Karel A. 1994. Pesantren, Madrasah, Sekolab: Pendidikan Islam dalam Kurun Moderen. Jakarta: LP3ES.

Subhan, Arief. 2012. Lembaga Pendidikan Islam Indonesia Abad Ke-20: Pergumulan Antara Modernisasi dan Identitas. Jakarta: Kencana Press. 